\title{
Plasmid-Mediated Fluoroquinolone Resistance in Pseudomonas aeruginosa and Acinetobacter baumannii
}

\author{
Geetha P. Venkataramana ${ }^{1} \quad$ Aishwarya K.V. Lalitha ${ }^{1}$ Shanthi Mariappan ${ }^{1} \quad$ Uma Sekar $^{1}$ \\ 1 Department of Microbiology, Sri Ramachandra Institute of Higher \\ Education and Research, Porur, Chennai, Tamil Nadu, India \\ J Lab Physicians 2022;14:271-277. \\ Address for correspondence Geetha P. Venkataramana, MSc, \\ Department of Microbiology, Sri Ramachandra Institute of Higher \\ Education and Research, Porur, Chennai, 600116, Tamil Nadu, India \\ (e-mail: gethu16@gmail.com).
}

\begin{abstract}
Keywords

- $\operatorname{aac}\left(6^{\prime}\right)-\mathrm{lb}-\mathrm{cr}$

- fluoroquinolones

- PMQR

Introduction Pseudomonas aeruginosa and Acinetobacter baumannii are important pathogens in health care-associated infections. Fluoroquinolone resistance has emerged in these pathogens. In this study, we aimed to determine the occurrence of plasmid-mediated quinolone resistance (PMQR) determinants ( $q n r A$, qnrB, qnrS, aac $\left(6^{\prime}\right)-l b-c r$, oqxAB, and qepA) by polymerase chain reaction (PCR) and the transmissibility of plasmid-borne resistance determinants in clinical isolates of $P$. aeruginosa and $A$. baumannii.

Materials and Methods The study included $P$. aeruginosa (85) and $A$. baumannii (45) which were nonduplicate, clinically significant, and ciprofloxacin resistant. Antibiotic susceptibility testing was done by disk diffusion method for other antimicrobial agents, namely amikacin, ceftazidime, piperacillin/tazobactam, ofloxacin, levofloxacin, and imipenem. Minimum inhibitory concentration of ciprofloxacin was determined. Efflux pump activity was evaluated using carbonyl-cyanide m-chlorophenylhydrazone (CCCP). The presence of PMQR genes was screened by PCR amplification. Transferability of PMQR genes was determined by conjugation experiment, and plasmid-based replicon typing was performed.

Results Resistance to other classes of antimicrobial agents was as follows: ceftazidime (86.9\%), piperacillin/tazobactam (73.8\%), imipenem (69.2\%), and amikacin (63.8\%). The minimal inhibitory concentration (MIC)50 and MIC90 for ciprofloxacin were 64 and greater than or equal to $256 \mu \mathrm{g} / \mathrm{mL}$, respectively. There was a reduction in MIC for 37 (28.4\%) isolates with CCCP. In P. aeruginosa, $12(14.1 \%)$ isolates harbored qnrB, 12 (14.1\%) qnrS, 9 (10.5\%) both qnrB and qnrS, 66 (77.6\%) aac( $\left.6^{\prime}\right)-l b-c r$, and 3 (3.5\%) oqxAB gene. In $A$. baumannii, qnrB was detected in 2 (4.4\%), 1 (2.2\%) harbored both the qnrA and qnrS, 1 isolate harbored qnrB and qnrS, 21 (46.6\%) aac $\left(6^{\prime}\right)-I b-c r$, and 1 $(2.2 \%)$ isolate harbored oqx $A B$ gene. Notably, qepA gene was not detected in any of the study isolates. Conjugation experiments revealed that 12 (9.2\%) were transferable. Of the transconjugants, seven (58.3\%) belonged to IncFIl type plasmid replicon, followed by four (33.3\%) IncA/C and one (8.3\%) IncFIC type.

Conclusion The plasmid-mediated resistance $a a c\left(6^{\prime}\right)-l b-c r$ gene is primarily responsible for mediating fluoroquinolone resistance in clinical isolates of $P$. aeruginosa and $A$. baumannii. The predominant plasmid type is IncFII.
\end{abstract}

published online

February 9, 2022
DOI https://doi.org/

$10.1055 / \mathrm{s}-0042-1742636$. ISSN 0974-2727. (c) 2022. The Indian Association of Laboratory Physicians. All rights reserved.

This is an open access article published by Thieme under the terms of the Creative Commons Attribution-NonDerivative-NonCommercial-License, permitting copying and reproduction so long as the original work is given appropriate credit. Contents may not be used for commercial purposes, or adapted, remixed, transformed or built upon. (https://creativecommons.org/ licenses/by-nc-nd/4.0/)

Thieme Medical and Scientific Publishers Pvt. Ltd., A-12, 2nd Floor, Sector 2, Noida-201301 UP, India 


\section{Introduction}

Fluoroquinolones are synthetic antimicrobial agents with a broad spectrum of activity. They are effective against a wide range of gram-negative and gram-positive pathogenic bacteria. Over the past few years, fueled by their wide use, resistance to fluoroquinolones has raised globally. ${ }^{1}$ An important resistance mechanism to fluoroquinolones is described by mutations in the quinolone resistance-determining regions of gyrase and topoisomerase encoding genes. $^{2}$ Another well-known fluoroquinolone resistance mechanism is the decreased intracellular drug accumulation by upregulation of efflux pumps or decreased expression of outer membrane porin. ${ }^{3}$ The emergence of plasmid-mediated quinolone resistance (PMQR) has been reported since 1998 . These are horizontally transferable and are referred to as "PMQR." The three PMQR genes include: (1) the $q n r$, (2) $a a c\left(6^{\prime}\right)-I b-c r$ (aminoglycoside acetyltransferase), and (3) oqxAB and qepA (efflux pumps). ${ }^{4}$

The plasmid $q n r$ genes ( $q n r A, q n r B$, and $q n r S$ ) encode for proteins of the pentapeptide repeat family that protect DNA gyrase and topoisomerase intravenous from fluoroquinolone inhibition. The $a a c\left(6^{\prime}\right)-I b-c r$ is a bifunctional variant of aminoglycoside acetyltransferase capable of modifying the fluoroquinolones that have an amino nitrogen on the $\mathrm{C} 7$ of piperazinyl ring, such as ciprofloxacin and norfloxacin, thereby reducing their activity. ${ }^{5}$ Other fluoroquinolones lacking an unsubstituted piperazinyl nitrogen are not affected. ${ }^{6}$ The plasmid-mediated qepA efflux pump belongs to the major facilitator superfamily that decreases susceptibility to hydrophilic fluoroquinolones, especially ciprofloxacin. $^{7}$ The $o q x A B$ encodes for efflux pumps belonging to the resistance nodulation division family and is a multidrug efflux pump. ${ }^{8}$

Acinetobacter baumannii and Pseudomonas aeruginosa are well recognized representatives of nonfermenting gramnegative pathogens which are responsible for health careacquired infections. In both species, resistance to fluoroquinolones has been a recognized problem due to their ready ability to acquire resistance determinants. ${ }^{2}$ Most studies on prevalence of PMQR genes are focused on Enterobacteriaceae. ${ }^{9-11}$ Data on the prevalence of PMQR genes among clinical isolates of $P$. aeruginosa and $A$. baumannii are scarce. $^{12}$

The presence of fluoroquinolone resistance genes on plasmid enables their spread to other bacterial species by horizontal gene transfer. The identification of related plasmids associated with specific resistance genes helps track the spread of resistant plasmids. Hence, polymerase chain reaction (PCR)-based replicon typing (PBRT) has been adopted worldwide as the method for plasmid identification and typing. ${ }^{13}$

In this study, we aimed to determine the occurrence of PMQR determinants ( $q n r A, q n r B, q n r S, a a c\left(6^{\prime}\right)-I b-c r, o q x A B$, and qepA) by PCR and the transmissibility of these plasmidborne resistance determinants in clinical isolates of $P$. aeruginosa and $A$. baumannii.

\section{Materials and Methods}

\section{Bacterial Isolates}

The study included $P$. aeruginosa (85) and A. baumannii (45) which were nonduplicate, clinically significant and ciprofloxacin resistant (as determined by disc diffusion test) and obtained from clinical specimens of hospitalized patients at university teaching hospital in South India. They were collected over a period of 1 year from July 2014 to June 2015. They were obtained from clinical specimens such as urine (5), exudative samples (66), respiratory secretions (47), and blood stream (12). The isolates were identified up to species level by automated system (VITEK2 GN-card; BioMerieux, Brussels, Belgium) and/or standard biochemical tests.

\section{Antimicrobial Susceptibility Testing}

Antibiotic susceptibility testing was done by Kirby-Bauer disc diffusion method for the following antimicrobials: ceftazidime (30 $\mu \mathrm{g})$, piperacillin/tazobactam $(30 \mu \mathrm{g})$, imipenem $(10 \mu \mathrm{g})$, amikacin $(30 \mu \mathrm{g})$, levofloxacin $(5 \mu \mathrm{g})$, and ofloxacin $(5 \mu \mathrm{g})$ (Himedia Laboratories, India). The minimal inhibitory concentration (MIC) of ciprofloxacin was determined by agar dilution technique according to CLSI 2017 guidelines. ${ }^{14}$ ATCC Escherichia coli 25922 was used as control for both disc diffusion method and MIC determination.

\section{Phenotypic Detection of Efflux Pump Activity}

To detect the presence of efflux pump mechanism, carbonylcyanide m-chlorophenylhydrazone (CCCP), the efflux pump inhibitor was added to each Muller-Hinton ( $\mathrm{MH}$ ) agar plate containing 0.125 to $256 \mu \mathrm{g} / \mathrm{mL}$ of ciprofloxacin. The fixed concentration of CCCP in the MH agar was $20 \mu \mathrm{g} / \mathrm{mL}$. The MIC with CCCP incorporated was determined in twofold serial dilutions as for the antibiotic (CLSI 2017). ${ }^{14} \mathrm{~A}$ plate without antibiotic and containing only CCCP inhibitor was used as control. The criteria for the presence of efflux pump activity was based on a fourfold decrease in MIC of ciprofloxacin on addition of $\mathrm{CCCP}^{15}$

\section{Polymerase Chain Reaction}

The DNA of the study isolates was extracted by the boiling method. The amplification of $q n r$ genes ( $q n r A, q n r B$, and qnrS) was performed by multiplex PCR using the cyclic profile: initial denaturation at $94^{\circ} \mathrm{C}$ for 7 minutes; denaturation at $94^{\circ} \mathrm{C}$ for 50 seconds, annealing at $53^{\circ} \mathrm{C}$ for $40 \mathrm{sec}-$ onds, and elongation at $72^{\circ} \mathrm{C}$ for 60 seconds, repeated for 35 cycles, and a final extension at $72^{\circ} \mathrm{C}$ for 5 minutes. ${ }^{16}$ The PCR conditions for $a c c\left(6^{\prime}\right)-I b-c r$ were: initial denaturation at $94^{\circ} \mathrm{C}$ for 7 minutes, denaturation at $94^{\circ} \mathrm{C}$ for 50 seconds, annealing at $55^{\circ} \mathrm{C}$ for 40 seconds, and elongation at $72^{\circ} \mathrm{C}$ for 60 seconds, repeated for 35 cycles, and a final extension at $72^{\circ} \mathrm{C}$ for 5 minutes. ${ }^{17}$ The PCR cyclic parameters for oqxAB were as follows: initial denaturation at $95^{\circ} \mathrm{C}$ for 15 minutes; 30 cycles of $94^{\circ} \mathrm{C}$ for 30 seconds, $63^{\circ} \mathrm{C}$ for 90 seconds, and $72^{\circ} \mathrm{C}$ for 90 seconds, followed by a final extension at $72^{\circ} \mathrm{C}$ for 10 minutes. The PCR conditions used for qepA were as follows: initial denaturation at $96^{\circ} \mathrm{C}$ for 1 minute, followed by 30 cycles of amplification at $96^{\circ} \mathrm{C}$ for 1 minute, annealing 
Table 1 Primers used in this study

\begin{tabular}{|c|c|c|c|}
\hline PMQR gene & Primers & Product size & Reference \\
\hline$q n r A$ & $\begin{array}{l}\text { 5'-TCAGCAAGAGGATTTCTCA-3' } \\
\text { 5'-GGCAGCACTATTA CTCCCA-3' }\end{array}$ & 516 & 16 \\
\hline$q n r B$ & $\begin{array}{l}\text { 5'-GATCGTGAAAGCCAGAAAGG3' } \\
\text { 5'-ACGATG CCTGGTAGTTGTCC-3' }\end{array}$ & 469 & 16 \\
\hline qnrS & $\begin{array}{l}\text { 5'-ACGACATTCGTCAACTGCAA-3' } \\
\text { 5'-TAAATTGGCACCCTGTAGGC-3' }\end{array}$ & 417 & 16 \\
\hline$a c c\left(6^{\prime}\right)-I b-c r$ & $\begin{array}{l}\text { 5'-TTGGAAGCGGGGACGGAM-3' } \\
\text { 5'-ACACGGCTGGACCATA -3' }\end{array}$ & 260 & 17 \\
\hline oqxAB & $\begin{array}{l}\text { 5'-CCGCACCGATAAATTAGTCG-3' } \\
\text { 5'-GGCGAGGTTTTGATAGTGGA-3' }\end{array}$ & 313 & 18 \\
\hline qepA & $\begin{array}{l}\text { 5-GCA GGT CCA GCA GCG GGT AG-3 } \\
\text { 5-CTT CCT GCC CGA GTA TCG TG-3 }\end{array}$ & 218 & 18 \\
\hline
\end{tabular}

Abbreviation: PMQR, plasmid-mediated quinolone resistance.

at $60^{\circ} \mathrm{C}$ for 1 minute, extension at $72^{\circ} \mathrm{C}$ for 1 minute, and the final extension step was at $72^{\circ} \mathrm{C}$ for 5 minutes. ${ }^{18}$ The primers used is given in - Table 1. ${ }^{16-18}$ The PCR by-product was examined by electrophoresis in agarose gel containing ethidium bromide and visualized by gel documentation system.

\section{DNA Sequencing}

The PCR positive amplicons were sequenced at SciGenome Labs Pvt, Ltd., India and analyzed with BLAST tools (www. ncbi.nim.nih.gov). The assigned GenBank accession number for the submitted sequences are: (1) MH709266 (qnrA); (2) KY130487 (qnrB); (3) KY130488 (qnrS); (4) MH709269 $\left(\operatorname{acc}\left(6^{\prime}\right)-I b-c r\right)$, and (5) MN273774 (oqxAB).

\section{Conjugation}

Conjugation experiments were performed for all PMQR positive isolates. Escherichia coli J53 AziR strain was used as the recipient and PMQR positive isolates as donor. The donor and recipient cells ( $0.5 \mathrm{~mL}$ each) in logarithmic phase were added to $3 \mathrm{~mL}$ of $\mathrm{LB}$ broth and incubated at $37^{\circ} \mathrm{C}$ overnight. Transconjugants were selected by plating on MacConkey agar plates containing sodium azide $(100 \mu \mathrm{g} / \mathrm{mL})$ and ciprofloxacin $(0.5 \mu \mathrm{g} / \mathrm{mL}){ }^{19}$ The transfer of PMQR genes in transconjugants was confirmed by PCR.

\section{Incompatibility Grouping of Plasmid Encoding Resistance for PMQR Genes}

Plasmid Inc group for the transconjugants was determined by PBRT. Five sets of multiplex PCR ([HI1, HI2, I1]; [X, L/M, N]; [FIA, FIB, W]; [YP FIC]; [A/C, T, FII $\mathrm{S}$ ]) and three simplex PCR $\left(\mathrm{F}_{\text {repB }}, \mathrm{K} / \mathrm{B}, \mathrm{B} / \mathrm{O}\right)$ were performed. ${ }^{13}$ The primers employed is depicted in - Table 2 . $^{13}$

\section{Results}

\section{Antimicrobial Susceptibility Testing}

All the study isolates were resistant to other fluoroquinolones-levofloxacin and ofloxacin. Resistance to other classes of antimicrobial agents was as follows: ceftazidime (86.9\%), piperacillin/tazobactam (73.8\%), imipenem (69.2\%), and amikacin (63.8\%). The MIC of ciprofloxacin ranged from 4 to greater than or equal to $256 \mu \mathrm{g} / \mathrm{mL}$. The $\mathrm{MIC}_{50}$ and $\mathrm{MIC}_{90}$ values were 64 and greater than or equal to $256 \mu \mathrm{g} / \mathrm{mL}$, respectively.

\section{Detection of Efflux Pump Activity}

Among 130 isolates, twofold reduction was evident in 46 (35.8\%) and fourfold or more reduction was observed in 37 (28.4\%). Fourfold was evident in 11 (12.9\%), 8-fold in 5 (5.8\%), 16 -fold in 7 (8.2\%), 32-fold in 3 (3.5\%), and 128 fold in 2 (2.3\%) among $P$. aeruginosa. In $A$. baumannii, 4-fold reduction was observed in one (2.2\%) isolate, 8 -fold in three (6.6\%), 16 -fold in two (4.4\%), and 64-fold in three (6.6\%), respectively (-Table 3).

\section{Polymerase Chain Reaction}

Among P. aeruginosa, qnr genes were detected in 36 (27.6\%) isolates, of which 12 (14.1\%) isolates harbored qnrB, 12 (14.1\%) carried qnrS gene, and 9 (10.5\%) isolates harbored both $q n r B$ and $q n r S$ genes. Among $A$. baumannii, qnrB was detected in two $(4.4 \%)$ isolates and only one $(2.2 \%)$ harbored both the qnrA and qnrS; 77.6\% (66) of P. aeruginosa and $46.6 \%$ (21) of $A$. baumannii isolates harbored $a a c\left(6^{\prime}\right)$-Ib-cr gene; $3.5 \%$ (3) of $P$. aeruginosa and $2.2 \%$ (1) of $A$. baumannii isolates harbored oqxAB gene. qepA gene was not detected in any of the study isolates. The PMQR genes encountered is depicted in -Table 4.

\section{PMQR Gene Transfer and Distribution of Plasmid Replicons}

In P. aeruginosa, 9.2\% (12/130) were transferred successfully. All the 12 transconjugants were positive only for $a a c\left(6^{\prime}\right)-I b$ cr gene. In A. baumannii, none of them was transferable.

The plasmid incompatibility types of the transconjugants were recognized by PBRT. Of the 12 transconjugants, 7 (58.3\%) belonged to IncFII type plasmid replicon, 4 (33.3\%) were IncA/C, and 1 (8.3\%) IncFIC type. 
Table 2 Primers for PCR-based replicon typing ${ }^{13}$

\begin{tabular}{|c|c|c|}
\hline $\begin{array}{l}\text { Replicon } \\
\text { type }\end{array}$ & Primer sequence $\left(5^{\prime}-3^{\prime}\right)$ & $\begin{array}{l}\text { Amplicon } \\
\text { size (bp) }\end{array}$ \\
\hline HI1 & $\begin{array}{l}\text { F-GGAGCGATGGATTACTTCAGTAC } \\
\text { R-TGCCGTTTCACCTCGTGAGTA }\end{array}$ & 471 \\
\hline $\mathrm{HI} 2$ & $\begin{array}{l}\text { F-TTTCTCCTGAGTCACCTGTTAACAC } \\
\text { R-GGCTCACTACCGTTGTCATCCT }\end{array}$ & 644 \\
\hline 11 & $\begin{array}{l}\text { F-CGAAAGCCGGACGGCAGAA } \\
\text { R-TCGTCGTTCCGCCAAGTTCGT }\end{array}$ & 139 \\
\hline$x$ & $\begin{array}{l}\text { F-AACCTTAGAGGCTATTTAAGTTGCTGAT } \\
\text { R-TGAGAGTCAATTTTTATCTCATGTTTTAGC }\end{array}$ & 376 \\
\hline L/M & $\begin{array}{l}\text { F-GGATGAAAACTATCAGCATCTGAAG } \\
\text { R-CTGCAGGGGCGATTCTTTAGG }\end{array}$ & 785 \\
\hline $\mathrm{N}$ & $\begin{array}{l}\text { F-GTCTAACGAGCTTACCGAAG } \\
\text { R-GTTTCAACTCTGCCAAGTTC }\end{array}$ & 559 \\
\hline FIA & $\begin{array}{l}\text { F-CCATGCTGGTTCTAGAGAAGGTG } \\
\text { R-GTATATCCTTACTGGCTTCCGCAG }\end{array}$ & 462 \\
\hline FIB & $\begin{array}{l}\text { F-GGAGTTCTGACACACGATTTTTCTG } \\
\text { R-CTCCCGTCGCTTCAGGGCATT }\end{array}$ & 308 \\
\hline W & $\begin{array}{l}\text { F-CCTAAGAACAACAAAGCCCCCG } \\
\text { R-GGTGCGCGGCATAGAACCGT }\end{array}$ & 242 \\
\hline Y & $\begin{array}{l}\text { F-AATTCAAACAACACTGTGCAGCCTG } \\
\text { R-GCGAGAATGGACGATTACAAAACTTT }\end{array}$ & 765 \\
\hline$P$ & $\begin{array}{l}\text { F-CTATGGCCCTGCAAACGCGCCAGAAA } \\
\text { R-TCACGCGCCAGGGCGCAGCC }\end{array}$ & 534 \\
\hline FIC & $\begin{array}{l}\text { F-GTGAACTGGCAGATGAGGAAGG } \\
\text { R-TTCTCCTCGTCGCCAAACTAGAT }\end{array}$ & 262 \\
\hline $\mathrm{A} / \mathrm{C}$ & $\begin{array}{l}\text { F-GAGAACCAAAGACAAAGACCTGGA } \\
\text { R-ACGACAAACCTGAATTGCCTCCTT }\end{array}$ & 465 \\
\hline $\mathrm{T}$ & $\begin{array}{l}\text { F-TTGGCCTGTTTGTGCCTAAACCAT } \\
\text { R-CGTTCATTACACTTAGCTTTGGAC }\end{array}$ & 750 \\
\hline $\mathrm{Fll}_{\mathrm{S}}$ & $\begin{array}{l}\text { F-CTGTCGTAAGCTGATGGC } \\
\text { R-CTCTGCCACAAACTTCAGC }\end{array}$ & 270 \\
\hline $\mathrm{F}_{\text {repB }}$ & $\begin{array}{l}\text { F-TGATCGTTTAAGGAATTTTG } \\
\text { R-GAAGATCAGTCACACCATCC }\end{array}$ & 270 \\
\hline $\mathrm{K} / \mathrm{B}$ & $\begin{array}{l}\text { F-GCGGTCCGGAAAGCCAGAAAA } \\
\text { R-TCTTTCACGAGCCCGCCAAA }\end{array}$ & 160 \\
\hline $\mathrm{B} / \mathrm{O}$ & $\begin{array}{l}\text { F-GCGGTCCGGAAAGCCAGAAAA } \\
\text { R-TCTGCGTTCCGCCAAGTTCGA }\end{array}$ & 159 \\
\hline
\end{tabular}

Abbreviation: PCR, polymerase chain reaction.

\section{Discussion}

Fluoroquinolones are potent antibiotics active against a broad range of bacteria. The global increase in the prevalence of clinical strains with reduced susceptibility to fluoroquinolones constitutes a major concern. ${ }^{20}$ The emergence of fluoroquinolone resistance among $P$. aeruginosa and $A$. baumannii presents a serious challenge in clinical management of bacterial infections. ${ }^{21}$ In this study, antibiotic susceptibility testing revealed that all the test isolates were resistance to the other fluoroquinolones also: levofloxacin and ofloxacin. Resistance to other class of antibiotics was ceftazidime (86.9\%), piperacillin/tazobactam (73.8\%), imipenem (69.2\%), and amikacin (63.8\%). In this study, 32.9\% (28) of P. aeruginosa and $37.7 \%$ (17) of $A$. baumannii isolates had an MIC of greater than or equal to $256 \mu \mathrm{g} / \mathrm{mL}$ to ciprofloxacin and similar observation has also been documented by Zaki et al. ${ }^{22}$

In this study, the MIC decrease factor value of fourfold and more reduction was evident in $28.4 \%$ (37/130) of isolates. In one isolate (4.5\%) (P. aeruginosa), it resulted in loss of ciprofloxacin resistance thus reflecting a highly active efflux activity as evidenced by the decrease in MIC from 256 to 0.5 $\mu \mathrm{g} / \mathrm{mL}$ on addition of CCCP inhibitor. Similar inhibition of efflux pump activity has been described previously. ${ }^{23,24}$ Researchers in the United States, Iran, and Bahrain have observed nonsignificant twofold reduction in MIC on addition of efflux pump inhibitor CCCP in $P$. aeruginosa. ${ }^{25-27}$ Helmy et al in their study reported significant efflux pump activity in A. baumannii and P. aeruginosa (46.1 and 41.1\%). ${ }^{28}$ Gomaa et al in Egypt recorded a high percentage of efflux pump-mediated resistance $(77.8 \%)$ in $A$. baumanni. ${ }^{29}$ In contrast, in South Africa, CCCP inhibitors did not affect MIC in A. baumanni. ${ }^{24}$

In this study, among qnr genes, $14.1 \%$ (12) were qnrB and $14.1 \%$ (12) were qnrS in $P$. aeruginosa which is a higher rate compared with a previous study from Egypt, which documented the presence of $q n r B$ and $q n r S$ genes in 1.8 and $2.7 \%$ of Pseudomonas spp. ${ }^{18}$ In contrast, El-Badawy et al and Rafiq et al documented high prevalence of qnrS (79.5 and $24 \%$ ) gene, respectively. qnrA and $q n r B$ were not detected in any of their isolates of Pseudomonas spp. ${ }^{30,31}$ Similar to the earlier study, qnrA gene was not detected in any of the isolates of $P$. aeruginosa in the present study. In China, a single isolate of $P$. aeruginosa with qnrA has been observed. ${ }^{32}$ In many other studies, qnr determinants were not detectable in clinical isolates of P.aeruginosa. ${ }^{33,34}$

Yang et al examined the prevalence of $q n r$ genes among 39 isolates of $A$. baumannii where 7.7\% (3/39) isolates harbored $q n r B$ and $2.6 \%$ (1/39) $q n r S .^{12}$ Hamed et al also reported the presence of qnrS gene in one isolate of $A$. baumannii. ${ }^{35}$ Touati et al observed qnrA gene in only one isolate in their study. ${ }^{36}$ In the present study, qnrB was encountered in two isolates singly. One isolate harbored qnrB and $q n r S$, while another carried both qnrA and qnrS.

Table 3 Effect of CCCP on the ciprofloxacin MIC

\begin{tabular}{|l|l|l|l|l|l|l|l|l|}
\hline Organism $(n=130)$ & \multicolumn{6}{l|}{ Fold reduction in MIC + CCCP $(\mu \mathrm{g} / \mathrm{mL})$} \\
\cline { 2 - 11 } & $\mathbf{0}$ & $\mathbf{2}$ & $\mathbf{4}$ & $\mathbf{8}$ & $\mathbf{1 6}$ & 32 & 64 & $\mathbf{1 2 8}$ \\
\hline Pseudomonas aeruginosa $(n=85)$ & 21 & 36 & 11 & 5 & 7 & 3 & 0 \\
\hline Acinetobacter baumannii $(n=45)$ & 26 & 10 & 1 & 3 & 2 & 0 & 3 \\
\hline
\end{tabular}

Abbreviations: CCCP, carbonyl-cyanide m-chlorophenylhydrazone; MIC, minimal inhibitory concentration. 
Table 4 Distribution of PMQR genes

\begin{tabular}{|c|c|c|c|}
\hline PMQR genes & $\begin{array}{l}\text { Pseudomonas aeruginosa } \\
(n=85)\end{array}$ & $\begin{array}{l}\text { Acinetobacter baumannii } \\
(n=45)\end{array}$ & $\begin{array}{l}\text { Total prevalence } \\
(n=130)\end{array}$ \\
\hline $\operatorname{aac}\left(6^{\prime}\right)-\mathrm{lb}-\mathrm{cr}$ & $31(36.4 \%)$ & $17(37.7 \%)$ & $48(36.9 \%)$ \\
\hline$o q \times A B$ & $1(1.1 \%)$ & $1(2.2 \%)$ & $2(1.5 \%)$ \\
\hline$q n r B+a a c\left(6^{\prime}\right)-l b-c r$ & $12(14.1 \%)$ & $2(4.4 \%)$ & $14(10.7 \%)$ \\
\hline$q n r S+a a c\left(6^{\prime}\right)-I b-c r$ & $12(14.1 \%)$ & 0 & $12(9.2 \%)$ \\
\hline$q n r A+q n r S+a a c\left(6^{\prime}\right)-I b-c r$ & 0 & $1(2.2 \%)$ & $1(0.7 \%)$ \\
\hline$q n r B+q n r S+a a c\left(6^{\prime}\right)-I b-c r$ & $9(10.5 \%)$ & $1(2.2 \%)$ & $10(7.6 \%)$ \\
\hline$q n r B+q n r S+o q x A B+a a c\left(6^{\prime}\right)-l b-c r$ & $1(1.1 \%)$ & 0 & $1(0.7 \%)$ \\
\hline$o q \times A B+\operatorname{aac}\left(6^{\prime}\right)-I b-c r$ & $1(1.1 \%)$ & 0 & $1(0.7 \%)$ \\
\hline Total & $67(78.8 \%)$ & $22(48.8 \%)$ & $89(68.5 \%)$ \\
\hline
\end{tabular}

Abbreviation: PMQR, plasmid-mediated quinolone resistance.

In Brazil, a low prevalence of $a a c\left(6^{\prime}\right)$ - $I b$ - $c r$ gene (2.6\%) was found in $P$. aeruginosa. ${ }^{37}$ Studies from Turkey and Egypt reported a high prevalence 56.4 and $79.5 \%$ in $P$. aeruginosa, respectively. This is similar to the findings of the present study (66.9\%). ${ }^{38}$ In this study, only four (3\%) isolates harbored oqxAB. Notably, qерA gene was not encountered. оqхAB and qерA genes were not identified in many other studies too. ${ }^{39-41}$

Conjugation experiments demonstrated that in $14.1 \%$ (12/85) of $P$. aeruginosa, PMQR determinants were successfully transferred and all the transconjugants harbored the $a a c\left(6^{\prime}\right)-I b$ cr gene. In A. baumannii, none of them was transferable. Jiang et al in their study documented that in $33.3 \%$ of nonfermenting gram negative bacteria (NFGNB), the transconjugants harbored the same PMQR determinants as their donors. ${ }^{42}$ In this study, more than one half of PMQR determinants, 59.2\% were nonconjugative, and this suggests that these genes may be of chromosomal location. Among the PMQR genes, high incidence of $a a c\left(6^{\prime}\right)-I b-c r(66.9 \%)$ was encountered and when conjugated, the transferability rate was $100 \%$ for this gene. This emphasizes that $a a c\left(6^{\prime}\right)-I b-c r$ gene plays a major role in mediating fluoroquinolone resistance. In the present study, of the 12 transconjugants, 33.3\% belonged to IncA/C type plasmid replicon. In Nigeria, IncF plasmid harboring $a a c\left(6^{\prime}\right)-I b-c r$ gene has been described in $P$. aeruginosa. ${ }^{43}$ A recent study in Argentina has demonstrated plasmid IncR group in $P$. aeruginosa. ${ }^{44}$

In this study, the prevalence rate of PMQR determinants is (68.5\%), which is higher than the rates in China (1.7\%), Egypt (4.5\%), and Nigeria (61\%). ${ }^{18,42,45}$ However, increasing rates of fluoroquinolone resistance have limited the treatment option. The approach of combined antibiotic therapies is an alternative to this phenomenon. ${ }^{46}$

The ciprofloxacin resistance isolates which were negative for PMQR genes in our study may probably harbor the chromosomal mutation genes (gyrA, gyrB, parC, and parE). These genes were not looked for in the present study.

\section{Conclusion}

Plasmid-mediated fluoroquinolone resistance is encountered in (78.8\%) of P. aeruginosa, while in A. baumannii, it is present in a proportion of $48.8 \%$ of clinical isolates. Single clinical isolate can harbor multiple PMQR genes. Plasmidmediated efflux fluoroquinolone resistance is responsible only for a small proportion of resistance to fluoroquinolone in clinical isolates of $P$. aeruginosa and $A$. baumannii. Of the plasmid efflux pump genes, only oqx $A B$ is present in $3 \%$ of isolates. It is reasonable to assume that of the plasmidmediated resistance, $a a c\left(6^{\prime}\right)-I b-c r$ is primarily responsible for mediating a major proportion of resistance to fluoroquinolones. IncFII is the predominant plasmid type followed by IncA/C and IncFIC type.

Funding

This study is funded by Department of Science \& Technology (DST) under Women Scientists Scheme (WOS-A).

Conflict of Interest

None declared.

\section{References}

1 Wang M, Tran JH, Jacoby GA, Zhang Y, Wang F, Hooper DC. Plasmid-mediated quinolone resistance in clinical isolates of Escherichia coli from Shanghai, China. Antimicrob Agents Chemother 2003;47(07):2242-2248

2 Bonomo RA, Szabo D. Mechanisms of multidrug resistance in Acinetobacter species and Pseudomonas aeruginosa. Clin Infect Dis 2006;43(2, Suppl 2):S49-S56

3 Hooper DC, Jacoby GA. Mechanisms of drug resistance: quinolone resistance. Ann N Y Acad Sci 2015;1354(01):12-31

4 Martínez-Martínez L, Pascual A, Jacoby GA. Quinolone resistance from a transferable plasmid. Lancet 1998;351(9105):797-799

5 Robicsek A, Jacoby GA, Hooper DC. The worldwide emergence of plasmid-mediated quinolone resistance. Lancet Infect Dis 2006;6 (10):629-640

6 Yamane K, Wachino J, Suzuki S, et al. New plasmid-mediated fluoroquinolone efflux pump, QepA, found in an Escherichia coli clinical isolate. Antimicrob Agents Chemother 2007;51(09): 3354-3360

7 Jacoby GA, Strahilevitz J, Hooper DC. Plasmid-mediated quinolone resistance. Microbiol Spectr 2014;2(05):10

8 Rodríguez-Martínez JM, Díaz de Alba P, Briales A, et al. Contribution of OqxAB efflux pumps to quinolone resistance in extended- 
spectrum- $\beta$-lactamase-producing Klebsiella pneumoniae. J Antimicrob Chemother 2013;68(01):68-73

9 Rodríguez-Martínez JM, Cano ME, Velasco C, Martínez-Martínez L, Pascual A. Plasmid-mediated quinolone resistance: an update. J Infect Chemother 2011;17(02):149-182

10 Yang $\mathrm{H}$, Chen $\mathrm{H}$, Yang $\mathrm{Q}$, Chen $\mathrm{M}$, Wang $\mathrm{H}$. High prevalence of plasmid-mediated quinolone resistance genes qnr and $a a c\left(6^{\prime}\right)-I b$ $\mathrm{cr}$ in clinical isolates of Enterobacteriaceae from nine teaching hospitals in China. Antimicrob Agents Chemother 2008;52(12): 4268-4273

11 Zhu YL, Yang H-F, Liu YY, et al. Detection of plasmid-mediated quinolone resistance determinants and the emergence of multidrug resistance in clinical isolates of Shigella in SiXian area, China. Diagn Microbiol Infect Dis 2013;75(03):327-329

12 Yang $\mathrm{H}, \mathrm{Hu}$ L, Liu Y, Ye Y, Li J. Detection of the plasmid-mediated quinolone resistance determinants in clinical isolates of Acinetobacter baumannii in China. J Chemother 2016;28(05):443-445

13 Carattoli A, Bertini A, Villa L, Falbo V, Hopkins KL, Threlfall EJ. Identification of plasmids by PCR-based replicon typing. J Microbiol Methods 2005;63(03):219-228

14 Clinical and Laboratory Standards Institute. Performance Standards for Antimicrobial Susceptibility Testing. M100. 27th ed. Wanye (PA): Clinical and Laboratory Standards Institute; 2017

15 Ardebili A, Talebi M, Azimi L, Rastegar Lari A. Effect of efflux pump inhibitor carbonyl cyanide 3-chlorophenylhydrazone on the minimum inhibitory concentration of ciprofloxacin in Acinetobacter baumannii clinical isolates. Jundishapur J Microbiol 2014;7(01): e8691

16 Robicsek A, Strahilevitz J, Sahm DF, Jacoby GA, Hooper DC. qnr prevalence in ceftazidime-resistant Enterobacteriaceae isolates from the United States. Antimicrob Agents Chemother 2006;50 (08):2872-2874

17 Wareham DW, Umoren I, Khanna P, Gordon NC. Allele-specific polymerase chain reaction (PCR) for rapid detection of the aac $\left(6^{\prime}\right)-\mathrm{Ib}-\mathrm{Cr}$ quinolone resistance gene. Int J Antimicrob Agents 2010;36(05):476-477

18 Saleh MA, Balboula MM. Plasmid mediated quinolone resistance determinants among nosocomial clinical Pseudomonas aeruginosa isolates. Int J Curr Microbiol Appl Sci 2017;6(01):42-50

19 Wang M, Tran JH, Jacoby GA, Zhang Y, Wang F, Hooper DC. Plasmid-mediated quinolone resistance in clinical isolates of Escherichia coli from Shanghai, China. Antimicrob Agents Chemother 2003;47(07):2242-2248

20 Pham TDM, Ziora ZM, Blaskovich MAT. Quinolone antibiotics. MedChemComm 2019;10(10):1719-1739

21 Navon-Venezia S, Ben-Ami R, Carmeli Y. Update on Pseudomonas aeruginosa and Acinetobacter baumannii infections in the healthcare setting. Curr Opin Infect Dis 2005;18(04):306-313

22 Zaki MES, Abou ElKheir N, Mofreh M. Molecular study of quinolone resistance determining regions of gyrA gene and parC genes in clinical isolates of Acintobacter baumannii resistant to fluoroquinolone. Open Microbiol J 2018;12:116-122

23 Chenia HY, Pillay B, Pillay D. Analysis of the mechanisms of fluoroquinolone resistance in urinary tract pathogens. J Antimicrob Chemother 2006;58(06):1274-1278

24 Osei Sekyere J, Amoako DG. Genomic and phenotypic characterisation of fluoroquinolone resistance mechanisms in Enterobacteriaceae in Durban, South Africa. PLoS One 2017;12(06): e0178888

25 Nikaido H, Pagès JM. Broad-specificity efflux pumps and their role in multidrug resistance of Gram-negative bacteria. FEMS Microbiol Rev 2012;36(02):340-363

26 Talebi-Taher M, Majidpour A, Gholami A, Rasouli-Kouhi S, Adabi M. Role of efflux pump inhibitor in decreasing antibiotic crossresistance of Pseudomonas aeruginosa in a burn hospital in Iran. J Infect Dev Ctries 2016;10(06):600-604

27 Al Rashed N, Joji RM, Saeed NK, Bindayna KM. Detection of overexpression of efflux pump expression in fluoroquinolone- resistant Pseudomonas aeruginosa isolates. Int J Appl Basic Med Res 2020;10(01):37-42

28 Helmy OM, Kashef MT. Different phenotypic and molecular mechanisms associated with multidrug resistance in Gram-negative clinical isolates from Egypt. Infect Drug Resist 2017; 10:479-498

29 Gomaa FM, Tawakol WM, El-Azm FI. Phenotypic and genotypic detection of some antimicrobial resistance mechanisms among multidrug-resistant Acinetobacter baumannii isolated from immunocompromised patients in Egypt. Egypt J Med Microbiol 2014;23(04):99-111

30 El-Badawy MF, Alrobaian MM, Shohayeb MM, Abdelwahab SF. Investigation of six plasmid-mediated quinolone resistance genes among clinical isolates of pseudomonas: a genotypic study in Saudi Arabia. Infect Drug Resist 2019;12:915-923

31 Rafiq K, Ahmad K, Ahmad N, Gohar M, Shehzad MA, Saeed MQ. Determination of Qnr allele frequencies in fluoroquinolone resistant Pseudomonas aeruginosa isolated from burn wounds. J Pak Med Assoc 2019;69(02):250-252

32 Yang X, Xing B, Liang C, Ye Z, Zhang Y. Prevalence and fluoroquinolone resistance of Pseudomonas aeruginosa in a hospital of South China. Int J Clin Exp Med 2015;8(01):1386-1390

33 Nazik H, Ongen B, Kuvat N. Investigation of plasmid-mediated quinolone resistance among isolates obtained in a Turkish intensive care unit. Jpn J Infect Dis 2008;61(04):310-312

34 Coban AY, Tanrıverdi Çaycı Y, Yıldırım T, Erturan Z, Durupınar B, Bozdoğan B. Investigation of plasmid-mediated quinolone resistance in Pseudomonas aeruginosa strains isolated from cystic fibrosis patients [in Turkish]. Mikrobiyol Bul 2011;45(04): 602-608

35 Hamed SM, Elkhatib WF, El-Mahallawy HA, Helmy MM, Ashour MS, Aboshanab KMA. Multiple mechanisms contributing to ciprofloxacin resistance among Gram negative bacteria causing infections to cancer patients. Sci Rep 2018;8(01):12268

36 Touati A, Brasme L, Benallaoua S, Gharout A, Madoux J, De Champs C. First report of qnrB-producing Enterobacter cloacae and qnrAproducing Acinetobacter baumannii recovered from Algerian hospitals. Diagn Microbiol Infect Dis 2008;60(03):287-290

37 Araujo BF, Ferreira ML, Campos PA, et al. Clinical and molecular epidemiology of multidrug-resistant $P$. aeruginosa carrying aac (6')-Ib-cr, qnrS1 and blaSPM genes in Brazil. PLoS One 2016;11 (05):e0155914

38 Cayci YT, Coban AY, Gunaydin M. Investigation of plasmid-mediated quinolone resistance in Pseudomonas aeruginosa clinical isolates. Indian J Med Microbiol 2014;32(03):285-289

39 Jafari M, Fallah F, Borhan RS, et al. The first report of CMY, aac (6')$\mathrm{Ib}$ and $16 \mathrm{~S}$ rRNA methylase genes among Pseudomonas aeruginosa isolates from Iran. Arch Pediatr Infect Dis 2013;1(03): $109-112$

40 Xue-qing Z, Dan-ping L, Chun-quan X, et al. Detection of plasmidmediated quinolone resistance determinants in clinical nonfermentative bacteria and ciprofloxacin sensitive Enterobacteriaceae strains. Dis Surveill 2014;29(02):130-135

41 Michalska AD, Sacha PT, Ojdana D, Wieczorek A, Tryniszewska E. Prevalence of resistance to aminoglycosides and fluoroquinolones among Pseudomonas aeruginosa strains in a University Hospital in Northeastern Poland. Braz J Microbiol 2015;45(04): $1455-1458$

42 Jiang X, Yu T, Jiang X, Zhang W, Zhang L, Ma J. Emergence of plasmid-mediated quinolone resistance genes in clinical isolates of Acinetobacter baumannii and Pseudomonas aeruginosa in Henan, China. Diagn Microbiol Infect Dis 2014;79(03):381-383

43 Ogbolu DO, Daini OA, Ogunledun A, Terry Alli OA, Webber MA. Dissemination of IncF plasmids carrying beta-lactamase genes in Gram-negative bacteria from Nigerian hospitals. J Infect Dev Ctries 2013;7(05):382-390

44 Elena A, Quinteros M, Di Conza J, Gutkind G, Cejas D, Radice MA. Full characterization of an IncR plasmid harboring qnrS1 
recovered from a VIM-11-producing Pseudomonas aeruginosa. Rev Argent Microbiol 2020;52(04):298-304

45 Ogbolu DO, Alli AO, Anorue MC, Daini OA, Oluwadun A. Distribution of plasmid-mediated quinolone resistance in Gram-negative bacteria from a tertiary hospital in Nigeria. Indian J Pathol Microbiol 2016;59(03):322-326
46 Castanheira M, Mendes RE, Jones RN. Update on Acinetobacter species: mechanisms of antimicrobial resistance and contemporary in vitro activity of minocycline and other treatment options. Clin Infect Dis 2014;59(6, suppl 6):S367-S373 